\title{
Utilization of biopesticides as sustainable solutions for management of pests in legume crops: achievements and prospects
}

Raj Kumar Mishra*, Abhishek Bohra, Naimuddin Kamaal, Krishna Kumar, Kiran Gandhi, Sujayanand GK, P. R. Saabale, Satheesh Naik SJ, Birinchi Kumar Sarma, Dharmendra Kumar, Monika Mishra, Dhirendra Kumar Srivastava and Narendra Pratap Singh

\begin{abstract}
Grain legumes remain important to meet the projected targets relating to food and nutritional security worldwide. The complementation of cereal-based food with grain legumes is a vegetarian diet with high-quality protein. However, the performance of these crops is severely influenced by a number of biotic and abiotic stresses, of which pests and pathogens remain the crucial affecting plants at different growth stages. Chemical pesticides are mainly employed across the world for management of pests and pathogens. The risk associated with the environmental pollution and health hazards to man, plants, domestic animals, and wild life makes these pesticides ecologically unacceptable. Also, major damage caused by pests of grain legumes are systemic in nature, and their management through chemicals often yields unsatisfactory outcome. This has led to increasing shift in the attention of scientific community towards eco-friendly and safer technologies for pest management in legumes. Sustainable protection demands implementation of strategies that rely upon biological control agents (BCAs) and their formulations. In recent years, such formulations have been promoted to mitigate the pest problem and improving crop yield. This review presents an updated summary on BCAs including the present status of BCA application, mode of actions, and delivery systems under controlled and field conditions to address major pest problems on legume crops.
\end{abstract}

Keywords: Legumes, Pest management, Biological control agents, Bioformulations, Ecological impacts

\section{Background}

The legume family is represented by nearly 400 genera and 10,000 species which harbors various pulse crops including chickpea (Cicer arietinum L.), pigeon pea (Cajanus cajan L.), field pea (Pisum sativum L.), lentil (Lens esculenta L.), green gram (Vigna radiata L.), black gram (Vigna mungoL.), cowpea (Vigna ungiculata L.), faba bean (Vicia faba), lathyrus (Lathyrus sativus), and rajmash (Phaseolus vulgaris L.), which are grown for both seeds and grains in different parts of the world (http://www.botany.hawaii.edu/faculty/carr/fab.htm).

Capable of releasing nitrogen into the soil, these crops are cultivated to obtain dry seeds that are rich in proteins and important minerals and micronutrients (Bohra et al., 2015, Nene, 2006). Frequent attacks by

\footnotetext{
* Correspondence: rkmishraiipr@gmail.com
}

ICAR-IIPR, Kanpur, India

pathogens, insect pests, and nematodes cause impairments to the plants at various stages of crop growth. The average annual loss in legumes due to pests and pathogens was estimated to be up to 20\% (Dhaliwal et al., 2010). In other words, the efforts dedicated to protect the crop may witness substantial increment in food legume production. Up to $100 \%$ losses have been reported in various legume crops in Asia and Africa in case of the conditions that favor diseases and pests (Vijay et al., 2015). In India, a considerable extent of yield in pigeon pea and chickpea is lost due to pod borer [Helicoverpa armigera (Hubner)]. In pigeon pea, spotted pod borer [Maruca vitrata (Fabricius)] remains the second most important pest causing up to $84 \%$ reduction in crop yield, amounting to a loss of nearly US $\$ 30$ million in monitory terms (Margam et al., 2011). Similarly, more than $40 \%$ damage to the pods in pigeon pea is caused by pod fly [Melanagromyza obtusa (Malloch)] (Singh et al., 
2013). The other pathogens that plague legume production include wilt, dry root rot, Phytophthora blight, collar rot, stem/white rot, Macrophomina blight, and yellow vein mosaic virus (YVMV). Losses caused by wilt in legumes may vary from 0 to $100 \%$ depending on the crop stage (Pande et al., 2013).

Besides being an expensive affair, the application of hazardous pesticides has detrimental effects on the environment, negatively impacting upon soil fertility and soil microfauna. Also, extended use of chemical pesticides not only often causes to the development of resistance (to pesticides) in insect pests, pathogens, and nematodes but also leads to carcinogenic, teratogenic, and mutagenic effects in human and animals as well. A range of strategies aiming to contain various pests and pathogens of grain legumes are currently available, which includes development of resistant varieties, genetically engineered plants, and use of pesticides and cultural and physical methods.

This review offers an update on the current status of biological control applications especially microbial organisms and their formulations in crops with an emphasis on legume crops. Future prospects of sustainable use of biological control agents (BCAs) to improve performance of legume crops are also discussed.

\section{Status of biological control agent (BCA) research and development}

An increase in selection pressure consequent to indiscriminate application of chemical pesticides leads to emergence of pesticide resistance. In such conditions, alternate options of pest/disease management are much sought. During the past two decades, an urgent need was realized for management strategies that are safe vis-a-vis the environment and the land. Farmers are shifting towards eco-friendly technology for the management of pests, i.e., BCAs or BCA-based formulations, referred to as biopesticides. Examples include Trichoderma spp., Pseudomonas spp., Bacillus spp., Agrobacterium radiobacter, nonpathogenic Fusarium spp., Coniothyrium spp. and Aspergillus niger, Bacillus thuringiensis (Bt), Metarhizium spp., Beauveria bassiana, and nuclear polyhedrosis virus (NPVs), which are popularly used in plant protection (Keswani et al. 2015; Mishra et al., 2015). According to a recent report (NAAS, 2013), nearly 1400 $\mathrm{BCA}$ products were sold and 175 biopesticide active ingredients and 700 products were registered worldwide for their commercialization. In India, only 15 biopesticides have been registered so far under the Insecticides Act 1968 (Table 1). A growing body of research articles report on the identification and efficacy of different BCAs against a number of pests and pathogens; however, their slow embrace is evident from the fact that only $2 \%$ biopesticides are currently used for crop protection worldwide.
Table 1 Biopesticides registered in India (Anonymous, 2014)

\begin{tabular}{lll}
\hline S. no. & Name of the biopesticide & Use for \\
\hline 1. & $\begin{array}{l}\text { Bacillus thuringiensis var. } \\
\text { israelensis }\end{array}$ & Diamondback moths \\
2. & Bacillus thuringiensis var. kurstaki & Diamondback moths \\
3. & Bacillus thuringiensis var. galleriae & Helicoverpa armigera \\
4. & Bacillus sphaericus & Diamondback moths \\
5. & B. firmus & Diamondback moths \\
6. & Trichoderma viride & Root rots and wilts \\
7. & Trichoderma harzianum & Root rots and wilts \\
8. & Pseudomonas fluorescens & Bacterial and fungal \\
9. & Beauveria bassiana & pathogen \\
10. & NPV of Helicoverpa armigera & Mango hoppers and mealy \\
11. & NPV of Spodoptera litura & Spodoptera litura \\
12. & Neem based biopesticides & Insect white fly \\
13. & Cymbopogon & Insect \\
14. & H. bacteriophora & Borers \\
15. & Trichogramma parasitoid & Sugarcane borers \\
\hline
\end{tabular}

On the positive side, the usage of BCAs has witnessed an increasing trend (Ranga Rao et al., 2007; Singh et al., 2012). The rise is notably high at international level. Though literature on BCAs is growing worldwide (Fig. 1), the filing of patents on BCA technology is not in sync with the number of publications.

Development of a stable and economically viable bioformulation remains central to biological control. Of the various carrier-based formulations available worldwide, alginate pellet- and talc-based formulations of BCAs have emerged as the most important carrier for the application in the management of crop diseases (Lewis et al., 1985). During initial phase of biological control development, it was viewed as an interaction of a single BCA with a pathogen in the rhizosphere (Wilson and Backman, 1999). Still, the majority of the reports on BCA document one target disease. This, however, has yielded inconsistent performance given that a single agent might not remain active in all soil conditions. Integrating microbes in a biological control formulation may serve as more effective management strategy in longer term (Duffy and Weller, 1995). Few biological control formulations based on combination of two or more BCAs are available in the market. Notwithstanding their significant role in sustainable agriculture, consortia-based formulations have not received adequate attention. Production of BCAs for sustainable agriculture relies on cost-effectiveness of the procedure and viability of a potential strain. Further, enabling mass production with high level of microbial count and viability also assumes greater significance. 


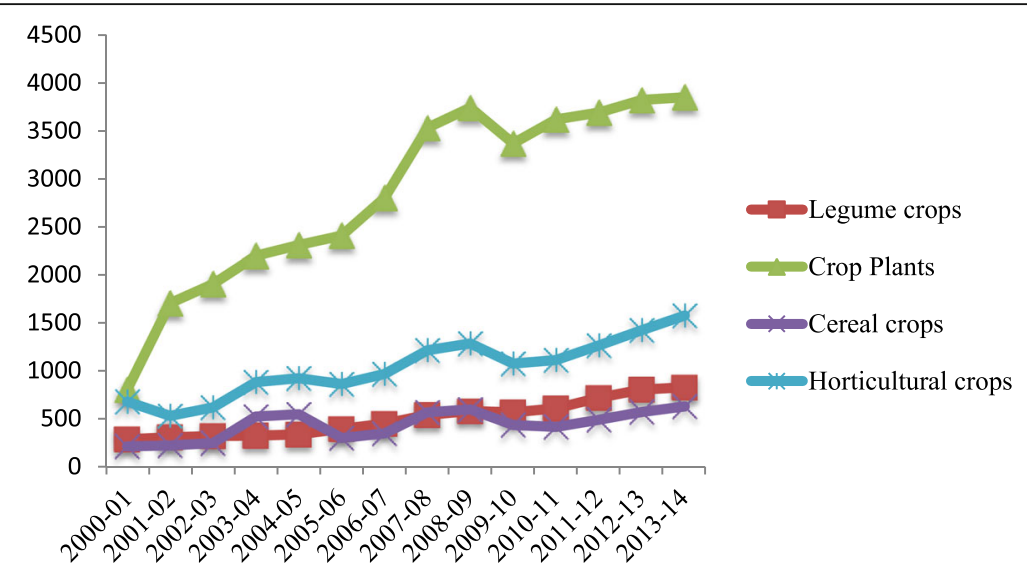

Fig. 1 Increasing use of BCAs in different crop plants as reflected in the form of patents and publications (from year 2000 to 2014, a rising trend is seen in the number of patents and publications pertaining to BCAs in plants. The data were obtained by searching the Google Scholar with biological control agents + formulations + diseases + insect + management + crop plants/legume crops as key words)

\section{Mechanism of BCAs}

BCAs interact with a variety of factors to control diseases and insect pests of crop plants. Therefore, an improved understanding of the BCA mechanisms can facilitate optimization of control in addition to permitting search for more efficient strains. Also, knowledge about the mechanisms underlying BCA-driven pest management may allow us to select and construct the BCAs with greater effectiveness. Studied by different researchers (Adams, 1990; Lo et al., 1998), these mechanisms encompass (i) antibiosis, (ii) competition, (iii) mycoparasitism/hyperparasitism, and (iv) induced resistance.

\section{Antibiosis}

The production of biochemicals by one microorganism that inhibits the growth of other organisms is known as antibiosis. Antibiotics generated by BCAs serve in different ways in order to minimize pests and pathogens. Production of multiple antibiotics probably helps suppress diverse microbial competitors, some of which are likely to be plant pathogens. More recently, Pseudomonas putida WCS358r strain was genetically engineered to produce phenazine, and 2,4-diacetylphloroglucinol (DAPG) had greater capacity to control plant diseases in fieldgrown wheat (Glandorf et al., 2001). Antibiotics thus produced generally are nonpolar/volatile, polar/nonvolatile, and water soluble. Among these, the greater effectiveness of volatile antibiotics can be accounted to their ability to serve at the sites away from the site of production. Table 2 enlists antibiotics produced by the BCAs that suppress the activity of plant pathogens. Delivered through sprays or expressed in plant, Bacillus thuringiensis (Bt) crystalline proteins (Cry toxins) manifest insecticidal activities against $H$. armigera (Dhillon and Sharma, 2010). Avermectins, milbemycins, and spinosyns, collectively forming macrocyclic lactones, are derived from culture broths of actinomycetes. Similarly, spinosyns are obtained through fermentation of two species of Saccharopolyspora (Herbert, 2010). According to Deshmukh et al. (2010), spinosyns and avermectins, ingredients in insecticides spinosad (45 SC at $0.009 \%$ ) and emamectin benzoate (5 SC at $0.0015 \%)$, respectively, remain highly effective against $H$. armigera population and pod damage in chickpea. Likewise, active rhizosphere colonizers Trichoderma harzianum and Trichoderma virens produce some cell wall-degrading enzymes (Larito et al., 1976), antibiotics such as gliotoxin and viridin (Tronsmo and Harman, 1992), and also certain biologically active heat-stable metabolites such as ethyl acetate, which inhibit various pathogens present in the soil. Studies have shown that $T$. harzianum, Trichoderma hamatum, and Pseudomonas fluorescence could be effective BCAs for management of lentil wilt caused by Fusarium oxysporum f. sp. lentis. Apart from producing antifungal enzymes, it negatively impacts wilt pathogen by posing competition for key nutrients and/or ecological niches (El-Hassan et al., 2013). Researchers have found chitinolytic activity in Bacillus cereus 28-9 (Huang et al., 2005) and Alcaligenes xylosoxidans (Vaidya et al., 2001). Likewise, chaetominis compound produced by Chaetomium globosum had significant role in antibiosis (Di Pietro et al., 1992).

\section{Competition}

Soils and plant surfaces constitute nutrient limited environment, thereby putting pressure on a microbe to compete for the available nutrients (Pal and Gardener, 2006). Both BCAs and the pests compete with each another for nutrients and space to establish in the environment. This process involves an indirect interaction between BCAs and pathogens, eventually resulting in pathogen exclusion by means of diminishing food base and physical occupation of site (Lorito et al., 1994). Also, BCAs 
Table 2 Antibiotics produced by BCAs for different target pathogens

\begin{tabular}{|c|c|c|c|c|}
\hline Source & Antibiotic & Target pathogens & Diseases & References \\
\hline Pseudomonas fluorescens F113 & 2,4-diacetyphloroglucinol & Pythium spp. & Damping off & Shanahan et al. (1992) \\
\hline Agrobacterium radiobacter & Agrocin 84 & Agrobacterium tumefaciens & Crown gall & Kerr (1980) \\
\hline Bacillus subtilis AU195 & Bacillomycin D & Aspergillus flavus & Aflatoxin contamination & Moyne et al. (2001) \\
\hline $\begin{array}{l}\text { Bacillus amyloliquefaciens } \\
\text { FZB42 }\end{array}$ & Bacillomycin, fengycin & Fusarium oxysporum & Wilt & Koumoutsi et al. (2004) \\
\hline Lysobacter sp. strain SB-K88 & Xanthobaccin A & Aphanomyces cochlioides & Damping off & Islam et al. (2005) \\
\hline Trichoderma virens & Gliotoxin & Rhizoctonia solani & Root rots & Wilhite et al. (2001) \\
\hline Pantoea Agglomerans C9-1 & Herbicolin & Erwinia amylovora & Fire blight & Sandra et al. (2001) \\
\hline B. subtilis QST713 & Iturin A & $\begin{array}{l}\text { Botrytis cinerea } \\
\text { R. solani }\end{array}$ & Damping off & $\begin{array}{l}\text { Paulitz and Belanger (2001), } \\
\text { Kloepper et al. (2004) }\end{array}$ \\
\hline B. subtilis BBG100 & Mycosubtilin & Pythium aphanidermatum & Damping off & Leclere et al. (2005) \\
\hline P. fluorescens 2-79 and 30-84 & Phenazines & $\begin{array}{l}\text { Gaeumannomyces graminis } \\
\text { var. tritici }\end{array}$ & Take-all & Thomashow et al. (1990) \\
\hline P. fluorescens Pf-5 & Pyoluteorin, Pyrrolnitrin & $\begin{array}{l}\text { Pythium ultimum } \\
\text { R. solani }\end{array}$ & Damping off & Howell and Stipanovic (1980) \\
\hline Burkholderia cepacia & Pyrrolnitrin, Pseudane & $\begin{array}{l}\text { R. solani } \\
\text { Pyricularia oryzae }\end{array}$ & Damping off and rice blast & Homma et al. (1989) \\
\hline Bacillus cereus UW85 & Zwittermicin A & $\begin{array}{l}\text { Phytophthora medicaginis } \\
\text { P. aphanidermatum }\end{array}$ & Damping off & Smith et al. (1993) \\
\hline Bacillus thuringiensis & Endotoxin & Helicoverpa armigera & Pod borer & Van Rie et al., (1990) \\
\hline
\end{tabular}

compete for the essential micronutrients such as iron (Fe) and manganese ( $\mathrm{Mn}$ ) especially in highly oxidized and aerated soils. However, the competition for micronutrients exists due to the BCAs having more efficient uptake system for the substances than the pests. While competing with pathogen for physical occupation of site, $\mathrm{BCAs}$ reduce or delay the root colonization by the pathogen. Owing to a rapid colonization of root surface of plants by the BCAs, the failure of pests and pathogens to establish on host helps lessening the severity of diseases that affect roots of plants.

\section{Parasitism}

Fungi that are parasitic on other fungi are usually referred to as mycoparasites (Baker and Cook, 1974). Parasitism requires the host fungus to be recognized by the mycoparasite followed by production of hydrolytic enzymes and antibiotics. Direct parasitism or lysis of the mycelium of a fungal pathogen by mycoparasitic fungus is known as hyperparasitism. Weindling (1932) observed Trichoderma lignorum parasitizing the hyphae of Rhizoctonia solani. The mycoparasitism of Trichoderma species enabled by appressoria-like structures to penetrate the target fungus cell wall (Chet, 1987) to contributes towards the development of biological control strategies (Harman et al., 2004). A range of pests with different kinds of parasitisms were observed viz., simple-, super-, multiple-, hyper-, auto-, and cleptoparasitisms. Larval parasitoid, Campoletis chlorideae, shows simple parasitism on $H$. armigera (Pillai et al., 2016). Similarly,
Maruca obtusa is parasitized by Euderus lividus at larval-pupal stages (Moudgal et al., 2005).

\section{Induced resistance}

Induced resistance varying from local to systemic in nature is the most indirect form of antagonism. With regard to systemic acquired resistance, salicylic acid (SA) and non-expresser of pathogenesis-related genes 1 (NPR1) are key players. Trichoderma harzianum when inoculated into the root system or on leaves of crops to manage the Botrytis cinerea on leaves spatially separated from the site of application of the BCA (Desmukh et al., 2006). While inducing resistance in plants, different kinds of compounds are released by Trichoderma spp. into the zone where the interaction occurs. Proteins with enzymatic or other activity constitute the foremost class in this regard. For instance, fungal proteins such as xylanase, cellulases, and swollenins are secreted by Trichoderma spp. (Martinez et al., 2001). Similarly, Trichoderma endochitinase can also enhance defense, probably through induction of plant defense-related proteins.

Physical thickening of cell walls in plants caused by BCAs contributes to induced resistance via diverse mechanisms that involve lignification, callose deposition and accumulation of antimicrobial low-molecular-weight substances (e.g., phytoalexins), and synthesis of chitinases, glucanases, peroxidases, and other pathogenesis-related (PR) proteins. Several endophytes such as Bacillus and Paenibacillus have been reported to inhibit soil-borne phytopathogens of pulse crops by production of 
siderophore, hydrolytic enzymes, antibiotics, and hydrogen cyanide (Senthilkumar et al., 2009). Florescent pseudomonad bacterium produces phenazine (Toohay et al., 1965), phloroglucinol (Howell and Stipanovic, 1980), siderophores (Sakthivel et al., 1986), and pyrrolnitrin (Burkhead and Geoghegan, 1994).

\section{BCAs and their formulations for pest management in legumes}

Considerable efforts have been made to manage important pests of legumes by incorporating BCA-colonized natural substrates into the rhizosphere. Bacterial endophytes like Bacillus, Paenibacillus, and Pseudomonas show antifungal activity against major pathogens like Rhizoctonia solani (Kuhn.), Rhizoctonia bataticola (Taub.) Butler, Fusarium udum Butler., F. oxysporum f. sp. cireri (Padwick) Snyd. \& Hans., and Sclerotium rolfsii Sacc. infecting pulse crops (Senthilkumar et al., 2009). Among the most pronounced antagonistic fungi, Trichoderma species have been extensively investigated as potential BCAs in pulse-based ecosystem. These are demonstrated to be effective against wilt and root rot (root, collar, and stem) diseases conditioned by different Fusarium spp., $R$. solani, $R$. bataticola, Sclerotium rolfsii, Sclerotinia sclerotiorum (Lib.) de Bary, Phytophthora drechsleri f. sp. cajani Tucker, and Pythium spp. in different pulses and other field crops (Chaudhary et al., 2004). The fungi belonging tohyphomycetes such as Metarhizium anisopliae, Beauvaria bassiana, Nomuraea, Verticillium, and Paecilomyces have been employed as biopesticides in legume crops. In soybean, the application of Paecilomyces lilacinus, Pochonia chlamydosporia, Aspergillus nidulans var. dentatus, and T. harzianum at $2 \mathrm{~g} / \mathrm{kg}$ soil can effectively reduce nematode (Rotylenchus reniform) population along with promoting plant growth (Gurjar et al., 2012; Singh and Prasad, 2014). Apart from controlling diseases in pulses, BCAs are also reported to enhance nodulation.

Several isolates of Trichoderma spp. have been characterized and evaluated against different fungal pathogens of pulse crops (Dubey et al., 2006; 2007; 2009; 2011; 2012; 2013; Jamali et al., 2004 Chaudhary et al., 2004; Mishra et al., 2015). A list of BCAs that are employed to manage different pests of pulses is given in Table 3. Besides, B. thuringiensis is one of the most promising biopesticides used worldwide for managing many lepidopterous pests. According to Roh et al. (2007), more than 100 Bt-based biopesticide formulations have been developed. Nuclear polyhedrosis viruses (NPVs) are specific biopesticides widely used in cotton, chickpea, pigeon pea, maize, groundnut, tomato, sorghum, sunflower, vegetables, and other crops (Pawar and Thombre, 1992).

Researchers at Indian Institute of Pulses Research (IIPR), India, has identified several native potential strains of Trichoderma spp. ( $T$. harzianum, $T$. asperellum, T. longibrachiatum, and T. reesei) and plant growth-promoting rhizobacteria (PGPRs) isolated from rhizospheres in major pulse-growing areas in India and evaluated these for their antagonistic potential against a variety of pathogens (Fig. 2a, b). Accordingly, mass production technology has been developed and popularized among the pulse-growing farmers in different agro-ecosystems (Chaudhary et al., 2004; Mishra et al., 2015, 2016).

\section{Types of BCA formulations}

BCAs are formulated by several means including dry formulations such as dusts, granules, and microgranules; seed dressing formulations such as powder for seed dressing; dry formulations for dilution in water including dispersible granules and wettable powders; and liquid formulations for dilution in water such as emulsions and suspension concentrates (Knowles, 2005, 2006). Globally, biopesticides are currently available in the market as wettable powder, liquid, and granular formulations (Singh et al., 2012, 2014). In pulses, researchers at IIPR employed $2 \%$ wettable powder formulations for seed treatment and soil application (Chaudhary et al., 2004).

\section{Wettable powders and liquids}

Generally, the BCAs such as fungal and bacterial species like Pseudomonas, Bacillus, and Trichoderma are applied as seed treatment and seedlings/root dip at the time of sowing (Tronsmo and Dennis, 1983). In pulses, 2\% talcbased formulation was found to be effective against wilt and root rot pathogens (Purushottam et al., 2014).

\section{Granular formulations}

As reported by Jones et al. (1984), lignite- and vermiculitebased granular formulations were used for management of soil-borne pathogens in different crops. Examples include alginate-based granular formulations of $T$. harzianum that are used to control $R$. solani in various crops.

\section{Delivery system of biological control formulations}

Biological control formulations and their consortia are delivered through several means relying primarily on survival nature and mode of infection of the pathogen. These diverse modes of application include seed treatment, soil/foliar application, or through workable combination of different methods. A brief description about these methods is provided here.

\section{Seed treatment}

This forms the most effective mode of applying BCAs, particularly to counter soil-borne phytopathogens. The hydration level of seed is controlled through techniques like seed priming which in turn allows the pregerminative metabolic activities while avoiding the emergence of the radical. Treating pigeon pea and 
Table 3 Management of major diseases of legumes by biological control agents

\begin{tabular}{|c|c|c|c|}
\hline Crops & Diseases & Pathogens & Effective biological control agents \\
\hline \multirow[t]{3}{*}{ Pigeon pea } & Wilt & Fusarium udum & Trichoderma harzianum, T. hamatum, T. viride, T. koningii, B. subtilus \\
\hline & $\begin{array}{l}\text { Phytophthora stem } \\
\text { blight }\end{array}$ & Phytophthora drechsleri f. sp. cajani & $\begin{array}{l}\text { T. harzianum, T. hamatum, Glomus mosseae, Pseudomonas fluorescens, } \\
\text { Bacillus subtilis }\end{array}$ \\
\hline & Seed-borne diseases & Pseudomonas campestris pv. vinae & T. viride, T. harzianum \\
\hline \multirow[t]{5}{*}{ Chickpea } & Wilt & Fusarium oxysporum f. sp. ciceri & Trichoderma harzianum, T. viride, T. virens, B. subtilus, A. niger AN 27 \\
\hline & Root rot & Rhizoctonia bataticola & Trichoderma harzianum, T. viride \\
\hline & Collar rot & Sclerotium rolfsii & T. viride, T. harzianum, P. fluorescens \\
\hline & Gray mold & Botrytis cinerea & Trichoderma spp. \\
\hline & Stem rot & Sclerotinia sclerotiorum & T. harzianum \\
\hline \multirow[t]{2}{*}{ Cowpea } & Wilt & Fusarium oxysporum & T. harzianum \\
\hline & Charcoal rot & $\begin{array}{l}\text { M. phaseolina, F. oxysporum f. sp. } \\
\text { tracheiphilum }\end{array}$ & T. viride, T. harzianum, T. koningii, T. pseudokoningii \\
\hline \multirow[t]{2}{*}{ Lentil } & Wilt & Fusarium oxysporum f. sp. lentis & T. viride, T. harzianum, G. virens, Pseudomonas fluorescens \\
\hline & Root rot & Macrophomina phaseolina & T. viride, T. harzianum, G. virens, P. fluorescens \\
\hline $\begin{array}{l}\text { Mung } \\
\text { bean }\end{array}$ & Root rot & M. phaseolina & T. harzianum, T. viride \\
\hline Soybean & Dry root rot & M. phaseolina & T. harzianum, T. viride \\
\hline \multirow[t]{3}{*}{ Field pea } & Rust & Uromyces fabae & Pseudomonas fluorescens, P. aeruginosa, Bacillus subtilis \\
\hline & Powdery mildew & Erysiphe polygoni DC & $\begin{array}{l}\text { T. harzianum, T. koningii, T. longibrachiatum, P. fluorescens, } \\
\text { Bacillus subtilis }\end{array}$ \\
\hline & Root rot & Rhizoctonia solani & T. harzianum, T. longibrachiatum, P. fluorescens, B. subtilis \\
\hline
\end{tabular}

chickpea seeds with talc-based formulation of T. harzianum, Trichoderma viride, T. hamatum, T. virens, Bacillus subtilis, and Pseudomonas fluorescens facilitates management of Fusarium wilt in both crops (Chet and Baker, 1981; Chand et al., 1991; Kaur and Mukhopadhayay, 1992; Vidhyasekaran et al., 1997; El-Hassan and Gowen, 2006; Khan et al., 2012). On-farm demonstrations have evidenced that the seed treatment with $2 \%$ talc-based formulation of Trichoderma harzianum (IPT31 ) led up to 32.1 and $14.3 \%$ decrease in root rot incidence in chickpea and lentil, respectively, thus correspondingly improving crop yield by 16.6 and $12.6 \%$ (Purushottam et al., 2014).

\section{Seed priming}

Priming of seeds with BCAs is a promising approach to protect seeds from various seed- and soil-borne pathogens. This technique is able to incite changes in plant characteristics apart from facilitating uniform seed germination (Bisen et al., 2015). Likewise, PGPRs also improve germination and seedling establishment. Callan et al. (1990) reported a 10-fold increase in the antagonist population load on the seeds as a result of seed bio-priming using bacterial antagonists, thus protecting rhizosphere from phytopathogen invasion. Priming of field pea seeds with Pseudomonas fluorescens, Pseudomonas aeruginosa, and Bacillus subtilis causes nearly 20\% decrease in incidence of Uromyces fabae under field conditions (Mishra and Pandey, 2010). Raguchander et al. (1998) reported that seed pelting with B. subtilis effectively controlled root rot (caused by Macrophomina phaseolina) in soybean.

\section{Soil application}

Trichoderma powder formulation can be applied into the soil prior to sowing or drenched at initial stages of crop growth. According to Vidhyasekaran and Muthamilan (1995), soil application of peat-based formulation with P. fluorescens (Pf1) at $2.5 \mathrm{~kg}$ of formulation mixed with $25 \mathrm{~kg}$ of well-decomposed farm yard manure improved management of chickpea wilt. Combining $P$. fluorescens with safer fungicides reduced the wilt complex in pigeon pea (Siddiqui et al., 1998). Likewise, seed treatment with wheat husk-based formulation of $T$. harzianum in chickpea reduced dry root rot incidence up to $28 \%$ as compared to $70 \%$ in untreated control (Parakhia and Vaishnow, 1986).

\section{Foliar spray}

Application of Trichoderma spp., Pseudomonas spp., and B. subtilis on leaves was reported to reduce the incidence of rust (Uromyces phaseoli) in beans (Baker et al., 1985). In a similar manner, seed treatment and foliar application of $P$. fluorescens (Pf1) reduced the severity of Puccinia arachidis of groundnut under field conditions (Meena et al., 2002). Under controlled environment, 

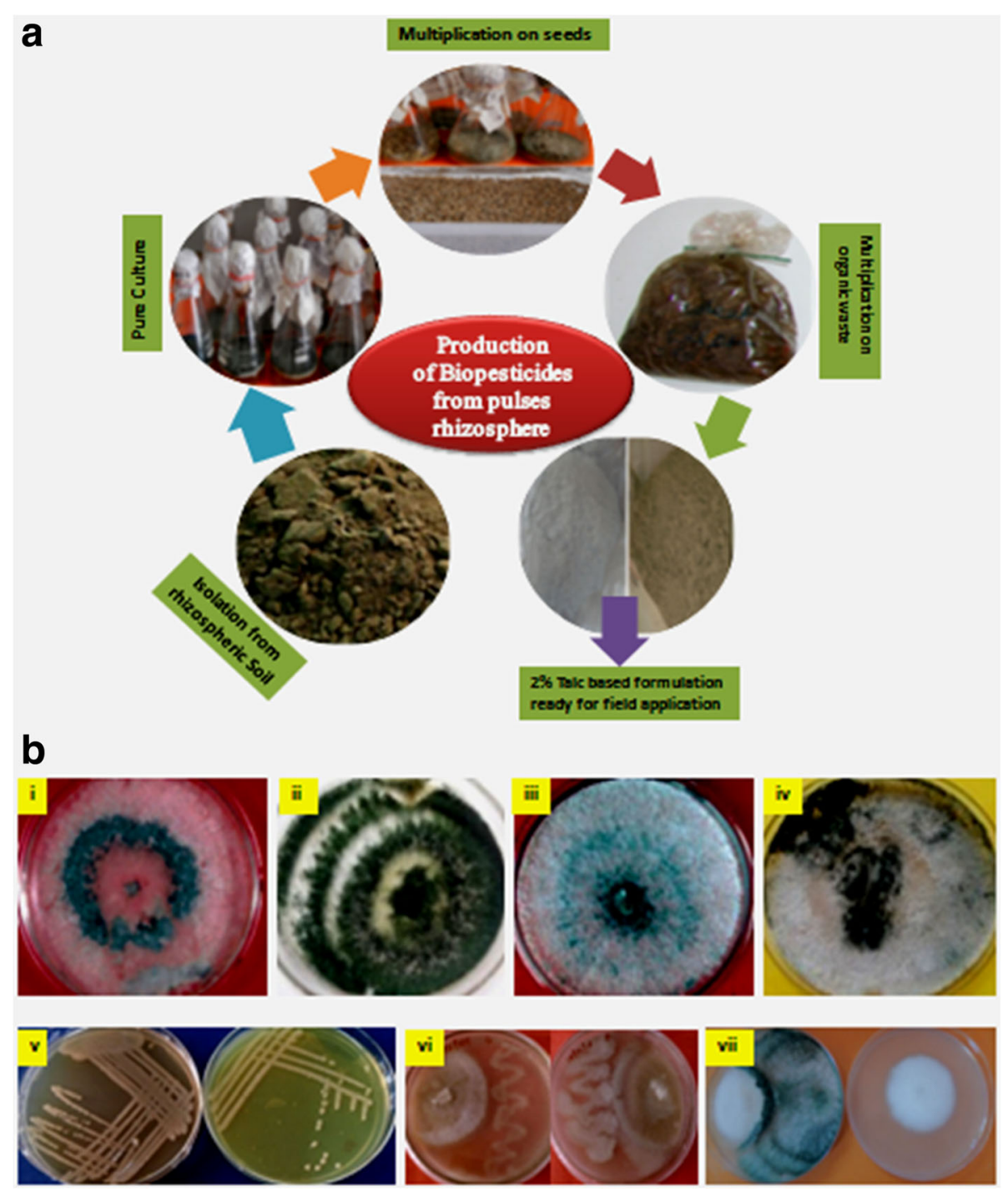

Fig. 2 a Procedure for formulation development. b Potential isolates of Trichoderma spp. from pulse rhizosphere in India: (i) Trichoderma harzianum, (ii) T. asperellum, (iii) T. longibrachiatum, (iv) T. reesei, (v) PGPRs, and antagonistic activity of (vi) PGPRs and (vii) Trichoderma spp. against F. udum

antagonistic activity of T. harzianum was demonstrated against botrytis gray mold (BGM) on chickpea foliage (Mukherjee and Haware, 1993). Ability of entomopathogenic PGPR strains to colonize phylloplane in a constant mode was notable with regard to foliar pest management in crop plants (Otsu et al., 2004).

\section{Commercialization of biological control products in legumes}

A series of experimentation and concerted efforts has led to commercialization of biological control products. The implementation of biological control products in managing plant diseases and insect pests is gaining ground. However, these still represent only $1 \%$ of the total plant protection products in comparison to fungicides accounting for $15 \%$ of total chemicals used in agriculture (Fravel, 2005). On the plus side, recent entry of several small- and large-scale entrepreneurs into commercial production of BCAs can be viewed as expanding scope of these in the world market.

As shown in Table 4, several formulations have been registered and available in the market for managing the crop pests. Unfortunately, no effective and potential host and region-specific stable formulation as well as consortia of biological product neither registered nor commercially available for pulses so far. Some potential biological control agents have been identified for management of Fusarium wilt and root rot diseases. In India, T. viride, Streptomyces gougeroti, and several bacterial species were shown to be functional against lentil wilt (Mehrotra and Claudius 1972). Similarly, T. harzianum and Trichoderma koningii showed antibiosis and 
Table 4 Commercial formulations registered in Indian market

\begin{tabular}{ll}
\hline Biopesticides & Registered formulations \\
\hline Trichoderma viride & $5 \% \mathrm{WP}$ \\
T. harzianum & $5 \% \mathrm{WP}$ \\
T. harzianum + T. viride + T. virens & $5 \% \mathrm{WP}$ \\
Bt var. kurstaki serotype H3a, H3b (HD-1) & $5 \% \mathrm{WP}, 2.5 \% \mathrm{AS}, 0.5 \% \mathrm{WP}$, \\
Bt var. kurstaki serotype H2a, 3b (NRD-12) & $3.5 \% \mathrm{AS}, \mathrm{WG}$ \\
Bt var. galleriae & $1.3 \% \mathrm{FC}$ \\
Bt var. israeliensis serotype H14 & Liquid and WP formulations, \\
& $5 \% \mathrm{AS}, 12 \% \mathrm{AS}$ \\
Bt sphaericus serotype H5a H5b & $1.3 \% \mathrm{FC}$ \\
B. sphaericus serotype B101 & \\
Verticilium lecanii & $1.15 \% \mathrm{WP}$ \\
Beauvaria bassiana & $1.15 \% \mathrm{WP}, 1.0 \%$ \\
Metarhizium anisopliae var. acridum & WP,1.15\%SC \\
HaNPV & $1.15 \% \mathrm{WP}$ \\
Consortia of T. harzianum and B. & $0.43 \% \mathrm{AS}$ or 2.0\% \\
thuringiensis & $\mathrm{AS}$ \\
T. harzianum (IIPRTh-1) & $2 \% \mathrm{WP}$ \\
\hline
\end{tabular}

mycoparasitism (Prasad and Rangeshwaran, 1999; Chaudhary et al., 2004; Mishra et al., 2015). Role of $B a$ cillus and Pseudomonas as biological control of bacterial wilt and root rot, respectively, in bean has been examined (Neeraj, 2011; Martins et al., 2013). Apprehensions that introducing foreign microbes could predispose existing microflora to disturbance warrant an elaborated examination of interactions involving foreign and native microbes, and this will also permit assessment of the negative impacts that such introductions exert on pulse rhizosphere.

\section{Challenges and prospects of BCAs in legume- based cropping system}

Pulses are grown mostly by the resource poor and smallscale farmers. Cultivation of these crops mostly in harsh and unpredictable environments renders these prone to attack by a wide range of pests and pathogens at various stages of the crops. The use of chemical pesticides as a control measure is not deemed environmentally safe, and at the same time, affordability of these chemicals by the marginal farmers also remains limited. Therefore, employing BCAs in pulses is safer in view of the fact that these crops are consumed directly as seeds.

In current agricultural scenario, the use of BCAs and their formulations is of utmost important in grain legumes for biotic stress management. However, their full potential remains to be seen because of the limited attention these have received so far in terms of commercial scale production of BCAs and formulations. In addition, commercially available formulations have not been accessible by the pulse growers. The major stumbling block impeding the progress in this regard is inadequate awareness about its application and advantages. This underlines the scope of making these BCAbased formulations and techniques popular at farmers' field.

The quality of BCAs and their different formulations and efficiency of the antagonist strain are utmost important. It is measured in terms of inoculum potential (propagules/unit weight and the aggressiveness), shelf life, and ease of application and purity of the formulation. Generally, the biological control formulations available in the market are of very poor quality with meager shelf life (Singh et al., 2012), which demand strict regulation through quality control agencies. Also, biological control agents despite of performing well under controlled environments may fail to yield the same results in the field conditions. Further, storage and marketing of microbial biopesticides is another issue that greatly limits the extensive use of BCAs in today's agriculture. It is a high time to educate the dealers and users (cultivators) on importance of appropriate storage conditions, shelf life, and mode of action of BCAs.

The pathogenic variability reported in soil-borne phytopathogens (especially in Fusarium spp. causing wilt) in many pulse crops poses a serious challenge aiming to develop potential BCAs. Further, before selecting BCA for developing its formulations, it should be thoroughly screened against a large number of phytopathogens or a large number of isolates/strains/races of phytopathogens.

Increasing development and deployment of such costefficient and environment-friendly techniques are the methods-of-choice to check the rising pest and pathogen problem and to sustain production of pulse crops in the face of growing agricultural adversities.

\section{Conclusions}

Grain legumes remain important crops not only from nutritional security perspective, but also for their contribution to the health and fertility of the soil. Cultivation of these crops faces a number of biotic and abiotic stresses, reflected in the form of deteriorated yield and quality. The use of chemicals, as a control measure, is not commercially viable. More importantly, it has considerable damaging consequences on the environment, soil and microorganisms. In this respect, BCAs have shown immense potential, thus increasingly playing a significant role in agricultural production systems. Management of pests and pathogens of legumes with BCAs offers several benefits over the traditional protection measures. We advocate application of BCAs in grain legumes crops in view of their potential to deliver sustained gains in crop productivity. 


\section{Acknowledgements}

The authors greatly acknowledge the Indian Council of Agricultural Research (ICAR), India, for the financial support.

\section{Authors' contributions}

RKM with $A B$ and NPS conceived the idea of the manuscript. RKM, $A B, N K$ and KK participated in preparing first draft of the manuscript. KG, SGK, PRS SNSJ, MM conducted literature surveys. BKS, DK and DKS provided inputs on BCA delivery systems. All authors read and approved the final manuscript.

\section{Competing interests}

The authors declare that they have no competing interests.

\section{Publisher's Note}

Springer Nature remains neutral with regard to jurisdictional claims in published maps and institutional affiliations.

Received: 15 July 2017 Accepted: 6 December 2017

Published online: 30 January 2018

\section{References}

Adams PB (1990) The potential of mycoparasites for biological control of plant diseases. Annu Rev Phytopathol 28:59-72

Anonymous. 2014. Global markets for biopesticides (http://www.bccresearch. com/report)

Baker CJ, Stavely JR, Mock N (1985) Biocontrol of bean rust by Bacillus subtilis under field conditions. Plant Dis 69:770-772

Baker KF, Cook RJ (1974) Biological control of plant pathogens. American Phytopathological Society, St. Paul, p 433

Bisen, K., Keswani, C., Mishra, S., Saxena, A., Rakshit, A., Singh, H. B. 2015. Unrealized potential of seed biopriming for versatile agriculture. Rakshit et.al, (eds.) Nutrient use efficiency from basics to advances, Springer, India, pp 193-205

Bohra A, Sahrawat KL, Kumar S, Joshi R, Parihar AK, Singh U, Singh D, Singh NP (2015) Genetics and genomics based interventions for nutritional enhancement of grain legume crops: status and outlook. J Appl Genet 56:151-161

Burkhead K, Geoghegan MJ (1994) Antibiotics. In: Burkhead K (ed) Soil-borne plant pathogens. Macmillon, New York, p 368

Callan NW, Mathre DE, Miller JB (1990) Bio-priming seed treatment for biological control of Pythium ultimum pre-emergence damping-off in sweet corn. Plant Dis 74:368-372

Chand H, Chhabra ML, Jalali BL (1991) Promising biocontrol agents for the control of chickpea wilt. Indian Phytopathology 46:36-39

Chaudhary RG, Shukla N, Prajapati RK (2004) Biological control of soil borne diseases: an updates in pulse crops. In: Shahid and Narain (ed) Ecofriendly management of plant diseases, pp 178-200

Chet I (1987) Trichoderma: application mode of action and potential as a biocontrol agent of soil borne of plant pathogenic fungi. In: Chet (ed) Innovative approaches to plant disease control I. John Wiley and Sons, New York, pp 137-160

Chet I, Baker R (1981) Isolation and biocontrol potential of Trichoderma hamatum from soil naturally suppressive of Rhizoctonia solani under field condition. Phytopathology 71(3):286-290

Deshmukh S, Hückelhoven R, Schäfer P, Imani J, Sharma M, Weiss M (2006) The root endophytic fungus Piriformospora indica requires host cell death for proliferation during mutualistic symbiosis with barley. Proc Natl Acad Sci U S A 103:18450-18457

Deshmukh SG, Sureja BV, Jethva DM, Chatar VP (2010) Field efficacy of different insecticides against $\mathrm{H}$. armigera (Hubner) infesting chickpea. Legum Res 33(4):269-273

Dhaliwal GS, Jindal V, Dhawan AK (2010) Insect pest problems and crop losses: changing trends. Indian Journal of Ecology 37:1-7

Dhillon MK, Sharma HC (2010) Chickpea-mediated effects of B. thuringiensis on H. armigera and its larval parasitoid, Campoletis chlorideae. J Appl Entomol 134: $682-693$

Di Pietro A, Gut-Rella M, Pachlatko JP, Schwinn FJ (1992) Role of antibiotics produced by Chaetomium globosum in biocontrol of Pythium ultimum, a causal agent of damping-off. Phytopathology 82:131-135

Dubey SC, Bhavani R, Singh B (2009) Development of Pusa 5SD for seed dressing and Pusa Biopellet $10 \mathrm{G}$ for soil application formulation of T. harzianum and their evaluation for integrated management of dry root rot of mung bean (Vigna radiata). Biol Control 50:231-242
Dubey SC, Singh B (2006) Integrated management of cercospora leaf spots and yellow mosaic of urdbean (Vigna mungo). Indian Journal Agricultural Sciences 76:485-489

Dubey SC, Suresh M, Singh B (2007) Evaluation of Trichoderma species against Fusarium oxysporum f. sp. ciceris for integrated management of chickpea wilt. Biol Control 40:118-127

Dubey SC, Tripathi A, Bhavani R, Singh R (2011) Evaluation of seed dressing and soil application formulations of Trichoderma species for integrated management of dry root rot of chickpea. Biocontrol Sci Tech 21:93-100

Dubey SC, Tripathi A, Singh B (2012) Combination of soil application and seed treatment formulations of Trichoderma species for integrated management of wet root rot caused by Rhizoctonia solani in chickpea (Cicer arietinum). Indian Journal of Agricultural sciences 82:356-362

Dubey SC, Tripathi A, Singh B (2013) Integrated management of Fusarium wilt by combined application of soil and seed dressing formulations of Trichoderma species to increase grain yield of chickpea. International Journal of Pest Management 59:47-54

Duffy BK, Weller DM (1995) Use of Gaeumannomyces graminis var. tritici alone and in combination with fluorescent pseudomonas spp. to suppress takes-all of wheat. Plant Dis 79:907-911

El-Hassan SA, Gowen SR (2006) Formulation and delivery of the bacterial antagonist Bacillus subtilis for management of lentil vascular wilt caused by Fusarium oxysporum f. sp. lentis. J Phytopathol 154(3):148-155

El-Hassan SA, Gowen SR, Pembrok B (2013) Use of Trichoderma hamatum for biocontrol of lentil wilts disease. Journal of Plant Protection Research 53(1):12-17

Fravel DR (2005) Commercialization and implementation of bio control. Annu Rev Phytopathol 43:337-359

Glandorf DCM, Verheggen P, Jansen T, Jorritsma JW, Smith E, Leeflang P, Wernars K, Thomashow LS, Laureijs E, Thomas-Oates JE, Bakker PAHM, Van Loon LC (2001) Effect of genetically modified Pseudomonas putida WCS358r on the fungal rhizosphere microflora of field grown wheat. Applied Environmental Microbiology 67:3371-3378

Gurjar HR, Sharma MK, Bhargav S, Srivastava AS (2012) Efficacy of fungal bioagents as soil application against Rotylenchulus reniformis. Indian Journal of Nematology 42:186-188

Harman GE, Howell CR, Viterbo A, Chet I, Lorito M (2004) Trichoderma species—opportunistic, avirulent plant symbionts. Nat Rev Microbiol 2:43-56

Herbert AK (2010) The spinosyn family of insecticides: realizing the potential of natural products research. The Journal of Antibiotic 63:101-111

Homma Y, Kato Z, Hirayama F, Konno K, Shirahama H, Suzui T (1989) Production of antibiotics by Pseudomonas cepacia as an agent for biological control of soilborne plant pathogens. Soil Biol. Biochem 21:723-728

Howell CR, Stipanovic RD (1980) Suppression of Pythium ultimum-induced damping-off of cotton seedlings by Pseudomonas fluorescens and its antibiotic, pyoluteorin. Phytopathology 70:712-715

Huang CJ, Wang TK, Chung SC, Chen CY (2005) Identification of an antifungal chitinase from a potential biocontrol agent, Bacillus cereus. Journal of Biochemistry Molecular Biology and Science 38:82-88

Islam MDT, Yasuyuki H, Abhinandan D, Toshiaki I, Satoshi T (2005) Suppression of Damping-Off Disease in Host Plants by the Rhizoplane Bacterium Lysobacter sp. Strain SB-K88 Is Linked to Plant Colonization and Antibiosis against Soilborne Peronosporomycetes. Applied and Environmental Microbiology 71(7):3786-3796

Jamali F, Sharifi-Tehrani A, Okhovvat M, Zakeri Z, Saberi-Riseh R (2004) Biological control of chickpea Fusarium wilt by antagonistic bacteria under greenhouse condition. Commun Agric Appl Biol Sci 69(4):649-651

Jones RW, Pettit RE, Taber RA (1984) Lignite and silage: carrier and substitute for application of fungal biocontrol agents to soil. Phytopathology 74:1167-1170

Kaur NP, Mukhopadhyay AN (1992) Integrated control of chickpea wilt complex by Trichoderma and chemical methods in India. Tropical Pest Management 38:372-375

Kerr A (1980) Biological control of crown gall through production of agrocin 84 Plant Disease 64:25-30

Keswani C, Mishra S, Sarma BK, Singh SP, Singh HB (2015) Unraveling the efficient application of secondary metabolites of various Trichoderma. Appl Microbiol Biotechnol 98:533-544

Khan RA, Bhat T, Kumar K (2012) Management of chickpea (Cicer arietinum L.) dry root rot caused by Rhizoctonia bataticola (Taub.) Butler. Int J Res Pharmaceut Biomed Sci 3(4):1539-1548

Knowles, A. 2005. New developments in crop protection product formulation. Agrow reports UK: T and F Informa UK Ltd, 153-156 
Knowles A (2006) Adjuvants and additives. T and F Informa UK Ltd, Agrow reports, London, pp 126-129

Koumoutsi A, Chen XH, Heune A, Liesegang $H$, Gabride H, Franke P, Vater J, Berris R (2004) Structural and functional characterization of gene clusters directing biocontrol agents. Pest Management Science 59:475-483

Larito P, Webster J, Lomas N (1976) Trichoderma viride produce gliotoxin and viridin. Transactions of British Mycological Society 47:535

Leclere V, Bechet M, Adam A, Guez JS, Wathelet B, Ongena M, Thonart P, Gancel F, Cholletlmbert M, Jacques P (2005) Mycosubtilin over-production by Bacillus subtitls BBG100 enhances the organism's antagonistic and biocontrol activities. Applied Environmental Microbiology 71:4577-4584

Lewis JA, Fravel DR, Papavizas GC, Lumsden RD (1985) Formulation and delivery systems for biocontrol agents effective against soil borne plant pathogenic fungi. In: Peppas N, Haluska RJ (eds) Proceedings of the 12th International Symposium on Controlled Release of Bioactive Materials. The Controlled Release Society, Lincolnshire, pp 341-342

Lo CT, Nelson EB, Hayes CK, Harman GE (1998) Ecological studies of transformed Trichoderma harzianum strain 1295-22 in the rhizosphere and on the phylloplane of creeping bentgrass. Phytopathology 88:129-137

Lorito M, Hayes CK, Zonia A (1994) Potential of genes and gene products from Trichoderma sp. and Gliocladium sp. for the development of biological pesticides. Mol Biotechnol 2:209-217

Margam VM, Coates BS, Ba MN, Sun W, Binso-Dabire CL, Baoua I, Ishiyaku MF, Shukle JT, Hellmich RL, Covas FG, Ramasamy S, Armstrong J, Pittendrigh BR, Murdock LL (2011) Geographic distribution of phylogenetically-distinct legume pod borer Maruca vitrata (Lepidoptera: Pyraloidea: Crambidae). Mol Biol Rep 38:893-903

Martinez C, Blanc F, Le CE, Besnard O, Nicole M, Baccou JC (2001) Salicylic acid and ethylene pathways are differentially activated in melon cotyledons by active or heatdenatured cellulase from Trichoderma longibrachiatum. Plant Physiol 127:334-344

Martins SJ, Vasconcelos FH, de Medeiros R, de Souza M, Vilela ML, de Resende P, Martins RJ (2013) Biological control of bacterial wilt of common bean by plant growth-promoting Rhizobacteria. Biol Control 66:65-71

Meena B, Radhajeyalakshmi R, Marimuthu T, Vidhyasekaran P, Velazhahan R (2002) Biological control of groundnut late leaf spot and rust by seed and foliar applications of a powder formulation of $P$. fluorescens. Biocontrol Sci Tech 12:195-204

Mehrotra RS, Claudius GR (1972) Biological control of root rots and wilts diseases of Lens culinaris Medic. Plant Soil 39:657-664

Mishra RK, Naimuddin, Krishna Kumar, Sujaynand GK, Jagdeeswaran R, Saabale PR, Akram M, Singh NP (2016) Production and popularization of biological control agents to enhance pulse production: an eco-friendly approach. ICARIndian Institute of Pulses Research, Kanpur

Mishra RK, Pandey KK (2010) Effect of application of PGPR and neemazal on management of pea rust (Uromyces fabae). Journal of Basic and Applied Microbiology 1\&2:115-119

Mishra RK, Saabale PR, Naimuddin, Jagadeeswaran R, Mishra O (2015) Potential Trichoderma sp. from pulses rhizosphere. Pulses newsletter, p 3

Moudgal RK, Lakra RK, Dahiya B (2005) Level of natural parasitisation of Melanagromyza obtusa (Malloch) (Diptera: Agromyzidae) on pigeon pea at Hisar. Entomon 30(3):273-274

Moyne AL, Shelby R, Cleveland TE, Tuzun S (2001) Bacillomycin D: an iturin with antifungal activity against Aspergillus flavus. Journal of Applied Microbiology 90(4):622-629

Mukherjee PK, Haware MP (1993) Biological control of botrytis gray mold of chickpea. International Chickpea Newsletter 28:14-15

NAAS (2013) Biopesticides-quality assurance. Policy paper no.62. National Academy of Agricultural Sciences, New Delhi, p 20

Neeraj KS (2011) Organic amendments to soil inoculated arbuscular mycorrhizal fungi and $P$. fluorescens treatments reduce the development of root-rot disease and enhance the yield of Phaseolus vulgaris L. European Journal Soil Biology 47:288-295

Nene YL (2006) Indian pulses through the millennia. Asian Agri-History 10(3):179-202

Otsu Y, Matsuda Y, Mori H, Ueki H, Nakajima T, Fujiwara K, Matsumoto M, Azuma N, Kakutani K, Nonomura T, Sakuratami Y, Shinogi T, Tosa Y, Mayama S, Toyode H (2004) Stable phyllosphere colonization by entomopathogenic bacterium Pseudomonas fluorescens KPM-018P and biological control of phytophagous ladybird beetles Epilachna vigintioctopunctata (Coleoptera: Coccinellidae). Biocontrol Sci Tech 14:427-439

Pal KK, B. McSpaddon Gardener (2006) Biological control of plant pathogens. The Plant Health Instructor:117-120. doi:https://doi.org/10.1094/PHI-A
Pande S, Sharma M, Gopika (2013) An updated review of biology, pathogenicity, epidemiology and management of wilt disease of pigeon pea (Cajanus cajan (L.) Millsp.) Journal of Food Legumes 26(1\&2):1-14

Parakhia AM, Vaishnav MV (1986) Bio-control of Rhizoctonia bataticola. Indian Phytopathology 39:439-440

Pawar VM, Thombre UT (1992) Prospects of baculovirus in integrated pest management of pulses. In: Ananthkrishnan TN (ed) Emerging trends in biocontrol of phytophagous insects. Oxford and IBH Publishing Company Private Limited, New Delhi, pp 253-258

Pillai AK, Selvaraj S, Agnihotri M (2016) Seasonal abundance of Campoletis chlorideae Uchida (hymenoptera: Ichneumonidae), a larval parasitoid of Helicoverpa armigera (Hubner) hardwick in chickpea. Legum Res 39(4):643-647

Prasad RD, Rangeshwaran R (1999) Granular formulation of Trichoderma and Gliocladium spp. in biocontrol of R. solani of chickpea. Journal of Mycology and Plant Pathology 29:222-226

Purushottam A, Swarnalakshmi K, Saabale PR, Ninawe AS (2014) On-farm demonstrations of Trichoderma harzianum in pulse crops under rainfed conditions of Bundelkhand-a case study. International Journal of Current Microbiology and Applied Science 3(11):471-478

Raguchander T, Rajappan K, Samiappan R (1998) Influence of biocontrol agents and organic amendment on soybean root rot. Int J Trop Agric 35:23-29

Ranga Rao GV, Rupela OP, Rameshwar Rao V, Reddy YVR (2007) Role of biopesticides in crop protection: present status and future prospects. Indian Journal of Plant Protection 35(1):1-9

Roh JY, Choi, Li MS, Jin BR, Je YH (2007) Bacillus thuringiensis as a specific, safe, and effective tool for insect pest control. Journal of Microbiology Biotechnology 17:547-559

Sakthivel N, Sivamani E, Unnmalai N, Gananamanickam S (1986) Plant growth promoting rhizobacterial in enhancing plant growth and suppressing plant pathogens. Curr Sci 55(1):22-25

Sandra Al, Wright CH, Zumoff LS, Steven VB (2001) Pantoea agglomerans strain EH318 produces two antibiotics that inhibit Erwinia amylovora in vitro. Applied Environmental Microbiology 67:282-292

Senthilkumar M, Swarnalakshmi K, Govindasamy V, Lee YK, Annapurna K (2009) Biocontrol potential of soybean bacterial endophytes against charcoal rot fungus, Rhizoctonia bataticola. Curr Microbiol 58:288-293

Shanahan P, O'Sullivan D, Simpson P, Glennon J, O'Gara F (1992) Isolation of 2,4diacetylphloroglucinol from a fluorescent pseudomonad and investigation of physiological parameters influencing its production. Applied Environmental Microbiology 58:353-358

Siddiqui ZA, Irshad Mahmood SH, Mahmood I, Hayat S (1998) Biocontrol of Heterodera cajani and Fusarium udum on pigeon pea using Glomus mosseae, Paecilomuces lilacinus and Pseudomonas fluorescens. Thai Journal of Agricultural Sciences 31:310-321

Singh A, Jain A, Sarma BK, Upadhyay RS, Singh HB (2014) Rhizosphere competent microbial consortium mediates rapid changes in phenolic profiles in chickpea during Sclerotium rolfsii infection. Microbiol Res 169:353-360

Singh AU, Prasad D (2014) Efficacy of fungal bioagents against Rotylenchulus reniform isatrum and other antagonists on sporulation of Botrytis cinerea on dead lily leaves exposed to field condition. Phytopathology 85:393-400

Singh HB, Singh BP, Singh SP, Sarma BK (2012) Exploring different avenues of Trichoderma as a potent biofortified and plant growth promoting candidate-an overview. Review of Plant Pathology 5:315-426

Singh RS, Chakravorty S, Chandra M (2013) Diversity of pod associated insect pests and natural enemies in pigeon pea, their relative abundance and crop losses in Bundelkhand region, India. Flora and Fauna 19(2):294-302

Smith KP, Havey MJ, Handelsman J (1993) Suppression of cottony leak of cucumber with Bacillus cereus strain UW85. Plant Disease 77:139-142

Thomashow LS, Weller DM, Bonsall RF, Pierson LS (1990) Production of the antibiotic phenazine I-carboxylic acid by fluorescent Pseudomonas species in the rhizosphere of wheat. Applied Environmental Microbiology 56:908-912

Toohay Jl, Nelson CD, Crotkov G (1965) Isolation and identification of two phenazines from a strain of Pseudomonas aureofaciens. Canadian Journal Botany 43:1055-1062

Tronsmo A, Dennis C (1983) The use of Trichoderma species to control strawberry fruit rots. Neth J Plant Pathol 83:449-459

Tronsmo A, Harman N (1992) Effect of temperature on antagonistic properties of Trichoderma species. Transactions of British Mycological Society 71:469

Vaidya RJ, Shah IM, Vyas PR, Chhatpar HS (2001) Production of chitinase and its optimization from a novel isolate Alcaligenes xylosoxydans: potential antifungal biocontrol. World J Microbiol Biotechnol 17:62-69 
Van Rie J, McGaughey WH, Johnson DE, Barnett BD, van Mellaert H (1990) Mechanism of insect resistance to the microbial insecticide Bacillus thuringiensis. Science 247:72-74

Vidhyasekaran P, Muthamilan M (1995) Development of formulations of Pseudomonas fluorescens for control of chickpea wilt. Plant Dis 79:782-786

Vidhyasekaran P, Sethuraman K, Rajappan K, Vasumathi K (1997) Powder formulation of Pseudomonas fluorescens to control pigeon pea wilt. Biol Control 8:166-171

Vijay P, Anil KC, Anchal D, Bana RS, Rana KS, Rana DS, Tyagi VK, Puniya MM (2015) Improved crop management practices for sustainable pulse production: an Indian perspective. Indian Journal Agricultural Sciences 85(6):747-758

Weindling R (1932) Trichoderma lignorum as a parasite of other soil fungi. Phytopathology 22:837-845

Wilhite SE, Lumsden RD, Straney DC (2001) Peptide Synthetase Gene in Trichoderma virens. Applied and Environmental Microbiology 67(11):5055-5062

Wilson M, Backman PA (1999) Biological control of plant pathogens. In: Ruberson JR (ed) Handbook of Pest management. Marcel-Dekker, Inc., New York, pp 309-335 www.botany.hawaii.edu/faculty/carr/fab.htm

\section{Submit your manuscript to a SpringerOpen ${ }^{\circ}$ journal and benefit from:}

- Convenient online submission

- Rigorous peer review

- Open access: articles freely available online

- High visibility within the field

- Retaining the copyright to your article

Submit your next manuscript at $\gg$ springeropen.com 